\title{
Armed Kinsmen and the Origins of the State
}

\author{
An Essay in Philosophical Anthropology
}

\author{
ALI A. MAZRUI \\ The University of Michigan, Ann Arbor, U.S.A.
}

$I_{1}$

$\mathrm{N}$ A BOOK about the role of political violence in some traditional African communities, Eugene Victor Walter adapted in a new way the categories suggested by E. R. Service to illustrate the nature of fundamental social organization. A "band" is regarded as the most rudimentary political community, involving literal face-to-face relationships. A band may have a leader, but there are no specialized political roles. A piece of land may be jointly exploited, or hunting may be jointly organized, but collective life is based on collective decisions and not on formal roles and carefully differentiated functions.

A "tribe" is a larger political community involving more than one residential unit. Walter limits the use of the term "tribe" strictly to what others have regarded as only one kind of tribal society-the stateless tribal society.

"Lacking officers and specialized political roles, it is integrated by segmentary lineages, clans, age grades, religious associations, or other corporate sodalities, which dramatize relationships that extend beyond the local units occupied with herding or agriculture, and they live in neolithic style... Bands and tribes are egalitarian societies, which shun formal distinctions of rank, but all the others are organized hierarchically."1

Walter's third type of political community is a "chiefdom", where the notion of a central focus of authority is finally institutionalized. The chief's functions, rights, privileges, and obligations are carefully defined and often limited. A chief organizes the labour of his people for public tasks, and is in charge of collecting revenue and distributing the wealth of his society, as well as of organizing and co-ordinating the functions of arbitration, collaboration, and conflict-resolution in that society.

Walter then passes on to a "state", an entity more complex than a chiefdom. The state has a greater degree of centralization, role specialization, and an emergent professionalization of certain services. But even more fundamental

1 Eugene Victor Walter, Terror and Resistance: A Study of Political Violence, with Case Studies of Some Primitive African Communities (London and New York: Oxford University Press, 1969) pp. 57-58. Walter was adapting E.R. Service, Primitive Social Organization (New York, 1962). 
than the difference in scale and complexity between a chiefdom and a state is the difference in the organization of purposeful social coercion.

"What distinguishes a state from a chiefdom is the nature and means of coercion authorized and exercised in the political community. In contrast to a chief, who can mobilize an armed force if necessary, the head of the state claims the legitimate monopoly of force and commands a special body of men organized to use it."2

Walter's categories, though open to challenge in some important respects, have decisive advantages in trying to understand the nature of political organization in Africa. But that may also be the disadvantage of the categories. Bands, tribes, and chiefdoms are less fundamental to political organization in Europe, North America, and Latin America than they are to Africa and to island societies in different parts of the world. Asia still has bands, tribes, and chiefdoms, but even in Asia these are less basic to the lives of the great majority of people than they are in the African continent.

In modern terms, Walter's category of "the state" is the most universal. We shall have to return to this as a special kind of polity, and estimate in what way the kinship factor remains pertinent to this level of political organization.

Nevertheless, in their very primordial implications, the other three categories put forward by Walter and Service do provide us with indicators about the origins of human organization, and the degree to which the political functions of man might have emerged out of roles which were originally those of an extended family.

What may be illuminating here is to relate Walter's four categories of band, tribe, chiefdom, and state to another set of categories-society, nation, and state. Again the state provides the element of overlapping universality in modern terms between these two categories. The state is the most governmentally oriented of all forms of political organization. At least to that extent, the state may also be the most political of all forms of human communities.

The question which arises is whether the state is also the least kinship oriented of all the categories we have mentioned. When the polity becomes the state, has it ceased to be an extended family? And how does all this development relate to the phenomenon of division of labour, both inter-sexual and intrasexual?

Two forms of survival have been at stake in the history of human collectivization-economic survival and military survival. We use economic here in the most basic sense - the organization of resources of livelihood and their exploitation for human purposes. The quest for economic survival was a major aspect behind the origins of society; the quest for military survival constituted part of the origins of the state. It is too often assumed that politics and economics have a special intimacy, that man is a political animal mainly because he has economic needs.

In fact, man was an economic agent before the polity as a distinctive organization came into being. Families had to cultivate land and bands had to

2 Walter, Ibid., p. 59. 
organize for hunting animals, even in situations where no political organizations or distinct political processes were discernible. Even the pre-political man was at the same time an economic agent. The real push towards the politicization of man lay not in economic but in military considerations. The processes of politicization and militarization were often intimately and mutually reinforcing. One of the great paradoxes of the growth of statehood in Europe was the emergence of the doctrine that the military must be apolitical. It may indeed be true that the culmination of statehood must ultimately lie in a viable divorce between politics and militarism; but this is compatible with the proposition that the very origins of political organization lay in military consideration. Perhaps the basic transition is from the warfare polity to the welfare polityand underlying that transition is the current of kinship as a system of political symbols.

\section{Kinship and Society}

We might ask ourselves which of Walter's four categories of human organization are in fact prepolitical, in spite of Walter's own assumptions that they are all different types of political organization. It is certainly arguable that the "band" is a prepolitical society, organized primarily for economic survival. In the history of political theory there has been a debate as to whether such bands were units of convenience or units of consanguinity. In a way it was the debate which John Locke had with Filmer. Did society originate in the free consent of individuals previously independent, as Locke maintained, or in the natural authority of a father over his children and children's children, as Filmer claimed? Filmer's position was in fact better anthropology, even if poorer philosophy, than that of Locke. There is far more concrete evidence in favour of the family, rather than the individual, as the basis of primordial society.

Filmer's own version of the family may have been excessively oriented towards a patriarchal organization. One does not have to believe in patriarchal authority in order to see kinship as part of the original basis of society. The organization of that kinship need not have involved an omnipotent father figure, exercising dictatorial authority over younger males, women and children. What is basic here is simply the distinction between society as an aggregation of families and society as a collection of individuals. Filmer was nearer to the former familial interpretation of the origins of society; Locke was nearer the latter individualist version. And it was Filmer, rather than Locke, who had anthropologists on his side, at least to some extent.

An additional advantage in the familial approach to the origins of society is the simple fact that it allows for a prepolitical society, before the birth of concepts such as "public purposes" and "public processes". Within relatively small scale extended families, the concept of "public" is not as yet meaningful. And we define the polity as a form of human organization large enough to allow for public functions in pursuit of collective goals. Politics is not merely the process of determining who gets what, when and where-but also how. The "how" 
includes the issue scale, and the extent to which collective life requires more than literal familial authority.

By the time we get to Walter's concept of the tribe, the politicization of kinship is already underway. The tribe in this sense is a stateless society, but it is not a pre-political society. On the contrary, the tribe in this sense is a social unit in which kinship ties play a particularly pronounced role in political organization.

But by this time the concept of the warrior has entered the scene. Politicization on this scale includes militarization. Initiation into adulthood for every young male often includes initiation into martial virtues. The organization of the functions, rights, and privileges of the warriors becomes an essential aspect of the polity. In some societies age grades come into play. Division of labour then involves not merely issues of economic survival but also issues of real or presumed military survival. There are occasions when the two are intimately intertwined. Raids for economic goods are themselves categories of military behaviour. Counter raids for cattle and sometimes women demand their own forms of military preparedness. Hobbes was right in linking the origins of political organization not only to economic competition but also to military glory. Hobbes saw in the nature of man three main causes of quarrel- "first, competition; secondly, diffidence; thirdly, glory". By diffidence, Hobbes meant the need for security. The pursuit of competitive advantage, security, and glory became central to the phenomenon of conflict itself.

"The first maketh man invade for Gain; the second, for Safety; and the third for Reputation. The first use violence to make themselves masters of other men's persons, wives, children and cattle; the second to defend them; the third, for trifles, as a word, a smile, a different opinion, and any other sign of undervalue, either direct in their persons or by reflection in their kindred, their friends, their nation, their profession or their name."3

The triple quest, for competitive advantage, general security and glory, was to Hobbes a basic aspect of human nature. For us, all we claim for that triple quest is that it provides the main area of interaction between the politicization and the militarization of human society.

A long term consequence of this equation between politics and militarism was the de-politicization of the female. The exclusion of women from the commanding heights of political decisions has its origins in this equation between politics and militarism.

Culture often changes in response to technological innovations. There is one aspect of culture which has resisted the cumulative technological revolutions-the simple cultural fact that it is men who go to the battlefield to fight wars. In the days when fighting involved fact-to-face confrontations, this sexual division of labour made sense. Primordial warfare with fists, clubs, or spears gave advantage to men as the taller and more muscular members of the species. Because the men fought the wars, it was they who reaffirmed the right to decide between war and peace. Such decisions required high political authority. In a

3 Hobbes, Leviathan, Part I, Chapter 2. 
sense, men became politically preeminent because they were militarily preeminent. And they became militarily preeminent because of an old factor in primordial kinship culture which gave the club or the spear to the spouse with greater muscular throwing power. It was thus that the male of the species was converted into the warrior.

Yet the technology of war has by now changed so fundamentally in technologically advanced societies that this particular division of labour needs no longer to be maintained. Intercontinental ballistic missiles require no male finger to press the button. The technology of B-52's requires no male pilot to drop the bombs. And yet the cultural equation between war and masculinity has persisted in spite of these technological revolutions. And partly because of that, the men have retained ultimate control of the polity as a whole to the present day in societies which are otherwise vastly different from each other. The warrior class remains a male class. Nations continue to send their sons to fight their wars, at least in the first instance. Even Israel makes her women equally liable to conscription without making them equally liable to service on the front line. Israel gave herself a woman prime minister-but presiding over a highly masculine cabinet, and certainly a highly masculine military establishment. ${ }^{4}$

Political stratification between the sexes is ultimately based on military considerations, even if political stratification within sexes is based on economic criteria. Men are above women in politics because men are warriors and not because men were in some societies the breadwinners. The role of the male as the warrior is more universal than as the breadwinner. Kinship and the polity have exerted an influence on stratification which bears a military insignia.

\section{Kinship and Nationhood}

If the aggregation of families led to the first prepolitical societies, the aggregation of small societies gradually led to the emergence of nations. In 1875 Henry Maine argued that the development of nationhood was in fact a transition from kinship to territoriality. At least in the earlier versions of his theory, Maine saw kinship in patriarchal terms. The bond of union within the group started by being a belief or fiction of common descent, and the myth of origin sacralized a common ancestor. The transition first from family to tribe, and then to nation was, in the words of Maine, "a system of concentric circles which have gradually expanded from the same point." 5

4 Consult also Ali A. Mazrui, "Phallic Symbols in Politics and War: An African Perspective" (Panel on Biology and Politics) and Ali A. Mazrui, "The Militarization of Charisma" (Panel on "Political Elites") 9th World Congress of the International Political Science Association, Montreal, August 20-25, 1973. These issues are discussed in a wider international context in a book by the same author still under preparation, and provisionally entitled $A$ World Federation of Cultures, sponsored by the Institute for World Order, New York, and the Carnegie Endowment for International Peace.

5 Maine, Ancient Law, Chapters V and VII. 
Maine then discussed the transition from bonds of kinship to the boundaries of territory.

\begin{abstract}
"We may bring home to oursclves the transformation of the idea in another way. England was once the country which Englishmen habited. Englishmen are now the people who inhabit England. The descendants of our forefathers keep up the tradition of kinship by calling themselves men of English race, but they tend steadily to become Americans and Australians. I do not say that the notion of consanguinity is absolutely lost; but it is extremcly diluted, and quite subordinated to the newer view of the territorial constitution of nations..."6
\end{abstract}

Although Maine's general theory was stimulating and has to a substantial extent been vindicated by history, he grossly underestimated the continuing residual political power of kinship. Territory has not replaced kinship as a basis of allegiance; it has simply introduced a new way of defining kinship. Territoriality is an extension of the old methods by which new members of a society were absorbed by an allocation of artificial kinship roles. Territoriality provides a broader definition of kinship, but by no means supplants it.

In England kinship, real or imaginary, is still a major factor behind attitudes to policies on both immigration and emigration. The Commonwealth Immigration Act of 1968 drew a sharp distinction between citizens who could successfully claim kinship ties with people in England and those who could not. The Act was intended to regulate the flow of British Asians from East Africa, as these individuals sought to claim what would otherwise have been a natural right of access to England as the country of their citizenship. But the British concept of citizenship was pre-modern at least in the sense of clinging substantially to presumed descent as a basis for the right of access to Britain.

Nor is this merely a racial factor, though racism played a large part in the events which led to the Commonwealth Immigration Act of 1968. In 1972, with Britain's impending entry into the European Common Market, a related issue of kinship arose. Would Italians and Germans as citizens of fellow members of the European Economic Community have easier access to Britain than New Zealanders and Australians? An initial draft put before Parliament by Edward Heath's government carried implications which made Australians and New Zealanders less favoured in terms of access to Britain than citizens of the other members of the European Economic Community. The debate culminated in a defeat of the government in Parliament, to the surprise of many observers. Edward Heath's government retreated from the original formulation of the legislation, and proceeded to revise it in a manner which would restore the rights of British "kith and kin" - now citizens of other countries-to have access to Britain on special consideration. The revised Act even made it difficult for the governments of Australia and New Zealand, since it discriminated by implication between Australians and New Zealanders who were of British origin and those who were not. Both governments in the antipodes expressed some anxiety about this differential treatment of their own citizenry in terms of

6 Sir Henry Maine, Lectures on the Early History of Institutions (New York, 1875). 
access to Britain. But for the time being the residual pull of kinship considerations seemed to have triumphed in England. The evidence would seem to suggest that Sir Henry Maine was a little premature in seeing kinship as an anachronistic factor in political allegiance. On the contrary, political phenomena which range from racism to regional integration have continued to be influenced by considerations of shared descent. Continental movements like the European Economic Community, on one side, and the British reluctance to use arms in overcoming Ian Smith in Rhodesia, on the other side, have all included various degrees of presumed kinship ties.?

When nationality is defined in "racial" terms, the issue of presumed consanguinity asserts its immediacy. Movements in Europe like Pan-Germanism and Pan-Slavism encompassed theories of nationhood based on shared blood. In Africa, the whole theory of apartheid rests partly on considerations of "kith and kin" and partly on the rationalization of cultural differentiation. In Uganda, Ficld Marshal Idi Amin has sought to create a nation of black Ugandans, partly on the grounds that black peoples are in a sense which is more than metaphorical what Amin would call "my brothers and sisters". And in the Middle East a whole new state was created in 1948, on the basis of shared descent from ancient Hebrews. The creation of Israel was once again an event deeply related to the interaction between kinship and nationhood. ${ }^{8}$

President Idi Amin of Uganda seems to have a general theory to the effect that people who are not prepared to mingle blood are not prepared to form a shared political community. The sexual exclusiveness of the Asians in Uganda prior to their expulsion led Amin to the conclusion that since Asians were not prepared to mingle blood with black Ugandans, they were by that very reluctance unprepared to share nationhood with Ugandans. There is considerable evidence to indicate that Amin adheres to this interpretation, and has by his own example encouraged transethnic marriages within the country. But there have been occasions when even he has been reported as being suspicious of Eurafricans and Eurasians. In February 1973 The Times of London reported that there were signs of "a new clampdown beginning on Eurafrican and

7 For a recent discussion of the supposed anachronism of kinship in British identity, consult Jerome Caminada, "Kith and Kin: A Myth Wearing Thin?" The Times (London) December 2, 1972.

8 For a more extensive comparison between Israel and Amin's Uganda as racially purist states consult Ali A. Mazrui, "Nation-Building and Race-Building: Israel and Amin's Uganda as Racially Purist States" (Panel on "Economy and Culture in the politics of Nation-Building"), 9th World Congress of the International Political Science Association, Montreal, August 20-25, 1973. For issues of nationhood in relation to race in Kenya, consult Donald Rothchild, "Kenya's Minorities and the African Crisis over Citizenship," Race (London) Vol. IX, No. 4, April 1968, pp. 421-437. See also the companion piece by Rothchild, "Citizenship and National Integration: The Non-African Crisis in Kenya," Studies in Race and Nations, Center on International Race Relations, Graduate School of International Studies, University of Denver, Vol. 1, Study 3, (1969-1970), 1970. 
Eurasian Ugandans, whom General Amin recently described as even bigger crooks than the Asians."9

The link between citizenship and readiness to engage in joint military selfdefence has certainly continued into the national scale of the growth of the polity. There was a time when citizenship itself could never be described as complete unless it included eligibility for military service.

"In the primitive nation as exhibited to us by its earliest records in Greece and Rome, and in the German tribes so far as they have a common permanent head, we find political functions distributed among threc differently constituted organs-the king or supreme chief, a council of subordinate chiefs or elders, and the assembly of fully qualified citizens which is ... a martial muster of the freemen in arms."10

In the growth of the Islamic Empire, the ultimate differentiating characteristic between fully absorbed citizens and conquered peoples was that the citizens were eligible for military service.

In Israel today the Arabs who are Israeli citizens fall short of being full citizens again by the yardstick of eligibility for military conscription. All Jewish Israelis are liable to military conscription, but not Arab Israelis. In a curious way the Arabs are second class citizens partly because the nature of a racially purist state like Israel is such that the non-Jew cannot be called upon for that ultimate sacrifice in war. Some countries have second class citizens by reducing the rights of the less privileged group; but both Israel today and Islamic states in the past had second class citizens by reducing the obligations of the less privileged groups.

Of all the countries in the world, perhaps the United States comes nearest to fulfilling Sir Henry Maine's criteria of territoriality as against kinship as the basis of nationhood. The mixture of nationalities and races in the composition of the population of the United States has certainly transformed the concept of "American" into a territorial concept par excellence. Territoriality as a basis of nationhood is even stronger in America than it is in those other immigrant countries like Australia and New Zealand. The greater mixture in the United States has oriented the history of the country precisely towards illustrating Sir Henry Maine's precept.

Even the duty to do military service in the American situation has been distinctive in being distributed not only among first class citizens, nor indeed only among citizens in lower classes, but also among resident aliens. The laws of the United States until recently allowed for the conscription of those who were territorially located in the United States, even if they had not as yet been granted citizenship, nor indeed applied for it. Even foreign students studying in

9 The Times (London) February 2, 1973. The General had presumably just been irritated by particular individuals, conceivably of mixed racial extraction, and was responding to the mood of the moment rather than to his interest in seeing black men mingle their blood with others as a form of black assertiveness.

10 Henry Sedgwick, The Development of European Polity (London: Macmillan and Company, 1920) p. 57. 
the United States at the peak of the Vietnam War were sometimes threatened with conscription by American authorities on the basis of the laws as they then existed.

But although the United States has perhaps gone furthest in the move from kinship to territoriality, it has still retained kinship factors as a force within its political system. Again issues of race and ethnicity, taboos of intermarriage and principles governing racial descent, have all had their ultimate roots in the dominant kinship culture of white Anglo-Saxon Protestants. The impact of Anglo-Saxon kinship on other groups has ranged from a desire by Italians or Jews to shed their names in preference for Anglo-Saxon names to the whole problem of racial disparities between black and white within the American society. Sir Henry Maine has not had it all his way in the United States.

\section{Kinship and Statehood}

There is a good deal of overlap between the evolution of the polity as nation and the polity as state. And both do link up with Eugene Victor Walter's concept of the chiefdom. In some parts of the world the principle of primogeniture in the family did help to consolidate the principle of hereditary succession in the chieftainship or kingship. Primogeniture sometimes implied the right of the eldest son to inherit the family. Primogeniture in Japanese society certainly tended in this direction, thought the system in England narrowed itself more to the right of the eldest son to inherit the title and the lands of his father. The question of how far Japanese and British principles of monarchical succession were conditioned by the broader doctrine of primogeniture in the wider society has remained one of the more intriguing issues in the political anthropology of monarchical institutions.

But apart from the impact of the wider kinship system on monarchical principles, there was also the political role of the monarch's relatives and the role of leading aristocratic families in societies like Japan and England. The polity in Japan and England has at times been indeed a family affair at least to the extent that elite recruitment has drawn so disproportionately from a number of distinguished upper class and upper middle class families. The polity as an extended family in such situations is almost literal, in spite of the enlarged scale of political organization in a nation of fifty million and more.

The behaviour of the monarch's relatives and the leading families in Japan and England bears a strong resemblance to the style of politics in chiefdoms in traditional Africa. Certainly the history of the British monarchy until this century when the monarchy became powerless was the history of an institution subject to the pulls of relatives and distinguished families within the realm, and therefore similar in important respects to experience in chiefly polities in Africa. In the words of Schapera:

"Tribal politics is in fact made up to a considerable extent of quarrels between the chief and his near relatives, and of their intrigues against one another to command his favour.... 
They are entitled by custom to advise and assist him in his conduct of public affairs, and they actively resent any failure on his part to give them what they regard as their due."11

The interplay between politics and militarism continues both at the level of chiefly polities and on the larger scale of imperial monarchical systems like those of Japan and Great Britain before World War II. Sons from distinguished families entered the military profession, thus partly consolidating the hold which their families already had over the political sector of the power structure in the land. The officer corps in such armies drew disproportionately from the illustrious kinship systems.

When statehood included imperial ambitions the interplay between politics and militarism was particularly strong. Again both Britain and Japan qualify in this regard. But so does Ashanti in Ghana's history. Fortes comments:

"The Ashanti state was created and maintained by war, and a military ideology remained a central feature of its structure to the end. Guns and gold were its training foundations. As imported firearms spread among the populace, the chiefdom which could muster the largest supplies of guns and ammunition had every chance, if ably led, to triumph in the intertribal wars." 12

That old link between economic survival and military survival had become in Ashanti a link between gold and guns by the 19th century. Statehood and imperial ambitions reinforced the military factor in the foundations of the Ashanti polity. It is here that we come back to the centrality of the concept of force in the very definition of statehood.

Statehood which is so defined has important points of contact with Max Weber's classic definition. Weber asserted that, sociologically, the state could not be defined in terms of its ends. Maintenance of law and order, preservation of society, promotion of the well-being of the community, control or suppression of deviant behaviour, may all be central to the purposes of the state. And yet Weber's point was that there is scarcely any task performed by the state that some political association has not taken in hand, and there is no task that one could say has always been exclusive and peculiar to those associations which are designated as political ones. To Weber, the modern state could be defined sociologically only in terms of the specific means peculiar to it, namely, the use of physical force.

Weber went on to quote Trotsky's belief that "every state is founded on force". Weber conceded that force is not the normal nor the only means of the state, but he regarded it as a means specific to the state.

"Today the relation between the state and violence is an especially intimate one. In the past, the most varied institutions-beginning with the sib-had known the use of physical force as quite normal. Today, however, we have to say that a state is a human com-

11 I. Schapera, "The Political Organization of the Ngwato of Bechuanaland Protectorate" in African Political Systems eds. M. Fortes and E. E. Evans-Pritchard (London and New York: Oxford University Press on behalf of the International African Institute, 1940, 1950 edition) p. 79.

12 M. Fortes, Kinship and the Social Order (Chicago: Aldine Publishing Company, 1963) p. 140. 
munity that 'successfully' claims the monopoly of the legitimate use of physical force within a given territory. Specifically, at the present time, the right to use force is ascribed to other institutions or to individuals only to the extent to which a state permits it. The state is considered the sole source of the 'right' to use violence." 13

Eugene Walter's own definition of the state mentioned earlier is Weberian since Walter sees the chief difference between a state and a chiefdom as lying in the nature and means of coercion authorized within the system and exercised in the political community. To Walter the head of state does claim "the legitimate monopoly of force and commands a special body of men organized to use it." 14

Radcliffe-Brown, M. Fortes, and Evans-Pritchard take the link even further, and assert that the control and manipulation of force is what all political organization is about, and not just what statehood is about.

"The political organization of a society is that aspect of the total organization which is concerned with the control and regulation of the use of physical force."15

British social anthropologists, by venturing into political anthropology, have helped political scientists to refine some of their concepts. And yet this should not blind us to the fact that the social anthropologists themselves betray a residual difficulty in distinguishing between statehood and a political system. Radcliffe-Brown invoked the principle of territoriality not only as part of a definition of a state but as part of a definition of political authority. To Radcliffe-Brown political authority is concerned with "the maintenance or establishment of social order, within a territorial framework, by the organized exercise of coercive authority through the use, or the possibility of use, of physical force." 16

Another major British anthropologist, John Beattie, has also embraced the principle of territoriality as part of the definition of "political authority". But Beattie goes on further and uses territoriality as a way of distinguishing political authority from authority in the family.

"I take authority to be 'political' only when its applicability depends upon, among other things, the occupation of a certain territory by the persons who acknowledge and are subject to it ... This is not the case with the, for example, domestic authority; a man's acknowledgement of his father's authority over him depends not, or not primarily, on where he is, but on what he is, that is, a son."17

13 Max Weber, "Politics as a Vocation", in H. H. Gerth and C. Wright-Mills, From Max Weber: Essays in Sociology (Routledge and Kegan Paul, 1957) p. 78. For the application of Weber's definition to the situation in Uganda consult Ali A. Mazrui, "The Lumpen Proletariat and the Lumpen Militariat: African Soldiers as a New Political Class," Political Studies (Oxford) Vol. XXI, No. 1, March 1973 and Mazrui, Cultural Engineering and Nation-Building in East Africa (Evanston, Illinois: Northwestern University Press, 1972) pp. 247-275.

14 Walter, Terror and Resistance, op cit., p. 59.

15 Fortes and Evans-Pritchard, African Political Systems, op. cit., pp. xxiii, 14.

16 A. R. Radcliffe-Brown, Preface to Fortes and Evans-Pritchard, African Political Systems, ibid., pp. xi-xxi.

17 John Beattie, The Nyoro State (Oxford: The Clarendon Press, 1971) pp. 4-5. 
Beattie is awakening us to the limits of regarding the polity as an extended family. While important kinship factors were still at play for a monarch like the Mukama of the Nyoro state, the nature of the Mukama's authority went beyond mere kinship. What Beattie does not fully grasp is that this is because the Mukama's authority was the authority of a head of state, and not merely because it was political authority. While territoriality remains pertinent to the very concept of statehood, it is not necessary as a basis for certain levels of political authority, nor does it necessarily replace the principle of kinship.

The issue of organization of physical force is more difficult to handle if we are to regard the state also as an extended family. Are the bonds which keep a family together ultimately definable in terms of the organization of physical force? We quote Weber again, "the most varied institutions - beginning with the sib - had known the use of physical force as quite normal." But although coercion is a factor which can condition the sib as a system of relationships, it is not a factor important for the sib's definition.

We are back now to the distinction between economic survival and military survival. The sib or family cooperates primarily for economic survival, at least in the sense of eking out a living and having bread to share. Statehood, on the other hand, has so far been the final consummation of that marriage between politicization and militarization. Is the state an extended family? The answer must be negative for as long as the ultimate impulse behind the state is the manipulation of force for public ends. The instincts of companionship and economic solidarity so basic to the survival of a primordial family are not the same as the impulses of organized coercion within a state as a militarized polity.

And yet the twentieth century has seen a closing of the gap between the ethos of an extended family and the ethos of modern statehood. A gradual transition, still incomplete, has started, from a warfare state to a welfare state. The emergence of the welfare state indicates a return to the principle of responsibility for the aged, the economically unproductive, and the infirm.

For the time being the welfare state coexists with the warfare state. Indeed, they are often fused in one. Principles of shared economic survival and policies of presumed military survival are conducted simultaneously. But the very emergence of the welfare state in the twentieth century signifies a reinforcement of the ethos of kinship in this particular kind of polity.

\section{Conclusion}

In his book, Primitive Society, Robert H. Lowie emphasized the role of associations as "potential agencies for the creation of a state by uniting the population within a circumscribed area into an aggregate that functions as a definite unit irrespective of any other social affiliations of the inhabitants." 18

In a later article on the origin of the state Lowie went on to say that "associations invariably weaken the prepotency of blood ties by establishing novel

18 Robert H. Lowie, Primitive Society (1920) pp. 394-396. 
ties regardless of kinship; and they may indirectly establish a positive union of all the occupants of a given area." 19

But Lowie came to have second thoughts before long on the issue of the autonomy of associations in relation to kinship within political processes.

\begin{abstract}
"Further study lcads to scrious modification of this vicw. Undoubtedly the claims set forth for the destructive efficacy of associations hold: by the very fact of their existence they have created novel bonds bound to encroach upon the omnipotence of kinship ties. But their positive achievement is more doubtful: it is only when supplementary factors of unification supervene that they achieve the solidarity of the entire local group. In itself, in other words, associational activity is not less scparatistic than the segmentation of socicty into groups of kindred." 20
\end{abstract}

Lowie sees the need for supplementary factors to give associational activity the driving integrative force. What he does not adequately work out is the impact of kinship itself as a factor behind the integrative functions of association. When political integration is an aggregation of subsocieties, it is quite often also an aggregation of kinship fields, real or fictitious.

The politicization of society had its origins less in economics than in combat. We have sought to illustrate in this paper that the growth of the polity in the direction of statehood was in part a process of militarization. The emergence of political authority was linked more to the dictates of military survival than the impulse of economic self-sufficiency. If Caesar's observations are to be relied upon, the German tribes in his time had chiefs in common only in wartime; as soon as peace was restored, the small clans had separate chiefs who administered justice and reconciled differences. The principle of expanding authority was closely tied to questions of military security rather than economic well-being. ${ }^{21}$

We have sought also to demonstrate how the kinship factor has played a part not only in the origins of human society but also in the system of symbols for races and nations in more recent times. The principle of territoriality behind the emergence of nations has simply transformed the mythology of kinship; it has not obliterated such mythologies. The range of implications in recent international history is from the doctrine of "kith and kin" in British immigration laws to the principle of a Jewish state as a basis for the creation of Israel, and from Field Marshal Idi Amin's expulsion of Asians in Uganda to the nature of interracial marriages in the United States. A particularly obstinate residue of a primordial division of labour is the subordination of woman to man both in politics and in war and the man emerged supreme not because he was supposed to be the bread-winner, but because he was supposed to be the warrior.

19 Lowie, "The Origin of the State", The Freeman Vol. V, July 19 and 26, 1922, p. 440-442, $465-467$.

20 Robert H. Lowie, The Origin of the State (New York: Harcourt, Brace and Company, 1927) pp. 107-108.

21 See Sidgwick, The Development of European Polity, op. cit., pp. 44-46. 